\title{
PERAN MEDIASI FINANCIAL BEHAVIOUR PADA FINANCIAL LITERACY TERHADAP FIRM PERFORMANCE
}

\author{
Jeneva Augustin ${ }^{1,}$ Saparila Worokinasih ${ }^{2,}$ Ari Darmawan ${ }^{3}$ \\ Fakultas Ilmu Administrasi, Universitas Brawijaya, Malang, Indonesia \\ Email: jenevaaugustin08.ur@gmail.com¹, saparila.fia@ub.ac.id², aridarmawan.fia@ub.ac.id ${ }^{3}$
}

\begin{abstract}
Financial literacy is a very important thing to be discussed further. In running a company or businesses in small, medium and large sectors, knowledge is needed to be able to run the business or company operations. This paper summarizes empirical research articles published between 2009 and 2019 that raise the topic of financial literacy. The articles reviewed in this paper look at the research gap, strengthen support for existing theories, and identify patterns among previous research. This review is expected to contribute theoretically to deepen the knowledge examined in financial literacy. Increased financial literacy in a person will be able to help companies to create reliable strategies. This reliable strategy can be seen with an increase in company performance. Firm performance in this case can be seen from a financial and non-financial perspective. Therefore, financial behavior is also a driving factor in improving the firm performance desired by business owners. financial behavior on a person will be motivated by financial literacy which can then improve firm performance. This paper aims to explain financial literacy, financial behavior and firm performance through previous studies or what is called literature review. Literature review in this paper will examine more closely related to financial literacy, financial behavior and firm performance.
\end{abstract}

Keywords: Financial Literacy, Financial Behaviour, Firm Performance

\begin{abstract}
ABSTRAK
Pengetahuan keuangan merupakan suatu hal yang sangat penting untuk dibahas lebih lanjut. Dalam menjalankan sebuah perusahaan ataupun usaha-usaha dalam sektor yang kecil, menengah maupun besar sangat dibutuhkan pengetahuan - pengetahuan untuk dapat menjalankan operasional usaha atau perusahaan tersebut. Pada paper ini merangkum artikel-artikel penelitian empiris yang dipublikasikan antara tahun 2009 dan 2019 yang mengangkat topik financial literacy. Artikel yang direview dalam tulisan ini untuk melihat research gap, memperkuat dukungan untuk teori yang ada, dan mengidentifikasi pola diantara penelitian terdahulu. Review yang dilakukan ini diharapkan dapat berkontribusi secara teoretis untuk memperdalam pengetahuan yang diteliti dalam financial literacy. Peningkatan pengetahuan keuangan pada diri seseorang akan dapat membantu perusahaan untuk menciptakan strategi yang handal. Strategi yang handal tersebut dapat dilihat dengan adanya peningkatan terhadap kinerja perusahaan. Firm Performance alam hal ini dapat dilihat dari sudut keuangan dan non keuangan. Maka dari itu, perilaku keuangan juga menjadi faktor pendorong dalam meningkatkan kinerja keuangan yang diinginkan oleh pemilik bisnis. Perilaku keuangan yang baik pada seseorang akan dilatarbelakangi oleh pengetahuan keuangan yang kemudian dapat meningkatkan kinerja perusahaan. Paper ini bertujuan untuk menjelaskan pengetahuan keuangan, perilaku keuangan dan kinerja keuangan melalui penelitian - penelitian terdahulu yang disebut dengan literature review. Literature review ada paper ini akan mengkaji secara lebih dalam terkait pengetahuan keuangan, perilaku keuangan dan kinerja perusahaan.
\end{abstract}

Kata Kunci: Pengetahuan Keuangan, Perilaku Keuangan, Kinerja Perusahaan. 


\section{PENDAHULUAN}

Persaingan bisnis yang terjadi pada era modern ditandai dengan hadirnya berbagai tantangan-tantangan dalam bisnis. Tantangan ini akan terjadi pada setiap perusahaan yang menjalankan bisnis secara berkelanjutan seperti, munculnya inovasi - inovasi produk yang dimiliki oleh perusahaan satu dengan perusahaan lainnya serta terjadinya percepatan informasi yang sangat cepat. Perusahaan yang berada pada tahap ini akan berusaha meningkatkan kemampuan yang dimilikinya untuk dapat mempertahankan bisnis sehingga mengharuskan perusahaan untuk menyesuaikan diri semakin cepat. Kemampuan dalam meningkatkan pengetahuan keuangan akan dapat meningkatkan kinerja perusahaan secara tidak langsung yang juga didukung oleh kecanggihan teknologi (Dai, 2016).

Menurut Oseifulah (2010) pemilik bisnis kebanyakan dikendalikan oleh mayoritas kalangan muda sebagai youth entrepreneur (pengusaha muda). Youth entrepreneur ialah generasi muda yang kebanyakan tertarik menjalankan serta mengoperasikan bisnis besar, mereka berani mengambil resiko keuangan yang lebih tinggi untuk menjalankan bisnisnya. Para youth entrepreneur merasa tertarik untuk menggeluti usaha bisnis dikarenakan beberapa faktor, antara lain seperti timbulnya keinginan untuk menciptakan kebebasan finansial dan untuk meningkatkan taraf hidup pada youth entrepreneur dengan didukung oleh pengetahuan keuangan yang dimiliki setiap pemiliki bisnis (Desyana \& Riyanti, 2017).

Peningkatan taraf hidup yang baik pada individu akan memperlihatkan baiknya kinerja perusahaan bisnis yang dijalankan pada tingkatan waktu tertentu (Krištofík, 2018). Keuntungan finansial yang diinginkan oleh semua pelaku bisnis mengharuskan mereka untuk dapat menciptakan strategi yang andal demi terwujudnya kebebasan finansial. Hal ini tidak terlepas dari pengetahuan - pengetahuan yang dimiliki oleh para pemilik bisnis yang menjalankan bisnis dengan segala aktivitas bisnisnya (Olieviera et al., 2019). Pengetahuan ini sangatlah penting untuk dipelajari dan dipahami disetiap waktu. Akan tetapi, tingkat literacy pada masyarakat indonesia terlebih lagi pada pengusaha muda selaku pemilik bisnis masih memiliki tingkat melek baca yang sangat rendah, Otoritas Jasa Keuangan (2018) apabila hal ini terus dibiarkan begitu saja akan berdampak secara langsung terhadap keuntungan yang akan diperoleh sebuah perusahaan. Sehingga hal ini secara langsung financial literacy memiliki dampak yang signifikan terhadap firm performance (Adomako \& Danso, 2014).

Secara nasional hasil pengukuran terhadap literasi keuangan pada tahun 2019 menggambarkan bahwa masyarakat pada rentang usia 20 - 40 tahun yang tergolong sebagai youth entrepreneur berada pada titik terendah dalam tingkat minat baca, sehingga dapat mempengaruhi pola pikir kinerja serta tindakan yang akan mereka lakukan kedepannya. Para youth entrepreneur sering sekali ketika menjalankan suatu bisnis mereka masih saja memiliki tingkat melek baca yang sangat rendah sehingga jika hal ini terus dibiarkan akan mempengaruhi tanggung jawab terhadap diri sendiri maupun perusahaan bisnisnya yang ketika menjalankan bisnis tersebut pengelolaan keuangan semakin tidak terarah dengan cermat (Listiani, 2017). Diketahui juga bahwa generasi muda sebagai youth entrepreneur masih jarang memperaktekkan kemampuan dasar tentang keuangan, seperti budgeting, pengelolaan uang masuk dan uang keluar, perencanaan anggaran atau perencanaaan untuk kebutuhan jangka panjang dan lain sebagainya (Herdjiono \& Damanik, 2016). Perencaanaan keuangan yang kurang matang pada youth entrepreneur akan berdampak buruk terhadap kinerja perusahaan (firm performance) dan jika hal ini terus menerus dibiarkan akan mengakibatkan perusahaan bisnis yang mereka jalankan menjadi bangkrut.

Selanjutnya bisnis ini mengalami kegagalan dikarenakan kurangnya business plan yang baik dan kurangnya analisis plan yang baik sebelum memulai bisnis, dan kegagalan selanjutnya karena pricing yang kurang strategis dan kemungkinan gagal tersebut juga dikarenakan tidak paham apa yang seharusnya dilakukan dan tidak dilakukan serta founder yang masih kurang self-efficacy dirinya (Kalaipriya, 2018). Oleh karena itu, pentingnya pengetahuan - pengetahuan dasar maupun pengetahuan yang lebih mendalam terkait financial sehingga dengan pengetahuan masyarakat Indonesia yang semakin membaik tersebut akan membuat perusahaan dapat bertahan dalam waktu yang lama.

Pengetahuan keuangan (financial literacy) mulai dikenal dan berkembang didunia bisnis dan akademis sudah beberapa tahun yang 
lalu. Perkembangannya dipelopori oleh adanya pengetahuan - pengetahuan yang diperlukan dalam proses pengambilan keputusan, sehingga dengan adanya financial literacy maka keputusan yang dilakukan para youth entrepreneur lebih terarah kedepannya (Ratnawati, 2016).

Financial literacy adalah kombinasi dari kesadaran, pengetahuan, keterampilan, sikap dan perilaku yang diperlukan untuk membuat keputusan keuangan yang baik dan dapat bertahan dalam jangka panjang akhirnya mencapai kesejahteraan finansial individu (Eniola \& Entebang, 2015). Financial Literacy juga didefinisikan sebagai proses yang digunakan individu sebagai kombinasi keterampilan, sumber daya, dan pengetahuan kontekstual untuk diproses sebagai informasi dan untuk membuat keputusan dengan pengetahuan dengan mempertimbangkan konsekuensi keuangan dari keputusan tersebut (Amanah, Iradianty, \& Rahardian, 2016). Menurut Humaira \& Sagoro (2018) financial literacy adalah mengukur sejauh mana seseorang memahami kunci konsep keuangan dan memiliki kemampuan dan kepercayaan diri untuk mengelola keuangan pribadi secara tepat, pengambilan keputusan jangka pendek dan perencanaan keuangan jangka panjang yang baik, sehingga dapat memperhatikan kehidupan peristiwa dan kondisi ekonomi yang berubah.

Financial literacy akan menjelaskan juga bagaimana pentingnya pengetahuan pengetahuan dasar keuangan (financial knowledge) yang berkaitan dengan pengelolaan pendapatan, pengeluaran, cara menyusun tujuan keuangan, mengatur keuangan tak terduga, melakukan tabungan di bank, mengetahui strategi investasi pada deposito, mengetahui strategi investasi pada saham dan mengetahui cara membuka polis asuransi (Lianto \& Elizabeth, 2017). Ketika individu sudah memiliki pengetahuan keuangan maka akan timbul presepsi dari sikapnya yang disebut dengan financial attitude. Financial attitude merupakan penilaian, pendapat, maupun keadaan pikiran seseorang terhadap keuangan yang diterapkan ke dalam sikapnya yang berkaitan dengan perencaanaan pengelolaan keuangan pribadi, mencatat seluruh transaksi keuangan, serta menabung uang untuk dana pensiun (Kumar et al., 2017).

Para pemilik bisnis yang menjalankan dan mengelola bisnisnya akan memiliki perilaku dalam diri mereka sendiri. Perilaku yang baik akan tergambar dari kesadaran mereka yang ingin mengetahui tentang keuangan. Financial behavior dalam hal ini terkait bagaimana mengendalikan pengeluaran, belajar membayar kewajiban (hutang) tepat waktu, serta memiliki manajemen hutang dan tabungan dalam mengambil keputusan (Assaf, 2019). Menurut Yohana (2010) mengatakan bahwa financial behavior sebagai pengelolaan keuangan secara efektif seperti mengatur penganggaran. Sedangkan secara keseluruhan dijelaskan oleh Amanah et al. (2016) financial behavior merupakan suatu tindakan dalam pengambilan keputusan keuangan, motif individu dari sudut pandang kognitif. Sedangkan menurut Hidayati (2019), ia mengatakan bahwa financial behavior tersebut merupakan suatu hal yang berkaitan dengan efektivitas manajemen dana. Financial behavior adalah suatu kemampuan seseorang yang dimilikinya dalam mengatur perencanaan keuangan, pengelolaan keuangan, pengendalian keuangan, pemeriksaan keuangan, pengendalian keuangan, dan bagaimana penyimpanan keuangan dalam dana sehari hari (Dwiastanti, 2015). Temuan Laili \& Haryono (2018), Uc Ediringhe et al. (2019) menunjukkan bahwa financial literacy mempengaruhi financial behavior.

Para pemilik bisnis sebagai youth entrepreneur akan menjalankan bisnis mereka dengan financial literacy yang mereka miliki. Pengetahuan tersebut akan memiliki dampak yang baik terhadap firm performance. Akan tetapi terdapat research gap yang mengatakan bahwa financial literacy tidak memiliki pengaruh terhadap firm performance. Adomako \& Danso (2014) yang menguji faktor-faktor yang mempengaruhi firm performance dan menemukan financial literacy memiliki pengaruh signifikan terhadap firm performance. Hal ini berbeda yang ditemukan oleh Eniola \& Entebang (2015) financial literacy berpengaruh tidak signifikan terhadap firm performance.

Temuan Esiebugie (2018) yang berbeda dengan penelitian Adomako \& Danso (2014) dan Esiebugie (2018) menunjukkan financial behavior berpengaruh tidak signifikan terhadap firm performance. Adomako \& Danso (2014) yang menguji variabel financial literacy dan financial behavior menunjukkan kedua variabel tersebut secara parsial berpengaruh signifikan terhadap firm performance.

Hal inilah yang membuat bisnis yang dijalankan oleh youth entrepreneur haruslah 
memiliki pengetahuan yang memadai agar tercapainya tujuan perusahaan. Tujuan perusahaan untuk meningkatkan keuntungan didapatkan dari semakin tingginya keinginan para pemilik bisnis selaku youth entrepreneur memahami pengetahuan, maka sebab itu financial behaviour seseorang akan menjadi lebih terarah terhadap firm performance.

Pada paper ini menggunakan literature review yang dimana dengan adanya literature review ini akan membuat peneliti selanjutnya lebih memahami terkait financial literacy. Pada paper ini juga akan menjelaskan lebih mendalam bagaimana penelitian-penelitian terdahulu meneliti financial literacy, financial behaviour dan firm performance secara lebih teliti dan cermat dan didukung juga dengan adanya research gap dalam penelitian.

\section{KAJIAN PUSTAKA \\ Financial Literacy}

financial literacy adalah kombinasi dari kesadaran, pengetahuan, keterampilan, sikap dan perilaku yang diperlukan untuk membuat keputusan keuangan yang baik dan dapat bertahan dalam jangka panjang akhirnya mencapai kesejahteraan finansial individu " (Esiebugie, 2018). Dalam beberapa tahun terakhir OECD dapat menjadi tolak ukur pertama kalinya untuk tingkat financial literacy di lingkungan globalisasi.

Financial Literacy juga didefinisikan sebagai proses yang digunakan individu sebagai kombinasi keterampilan, sumber daya, dan pengetahuan kontekstual untuk diproses sebagai informasi dan untuk membuat keputusan dengan pengetahuan dengan mempertimbangkan konsekuensi keuangan dari keputusan tersebut (Sanistasya, Raharjo, \& Iqbal, 2019). Menurut Esiebugie (2018) financial literacy adalah mengukur sejauh mana seseorang memahami kunci konsep keuangan dan memiliki kemampuan dan kepercayaan diri untuk mengelola keuangan pribadi secara tepat, pengambilan keputusan keuangan yang baik seperti memiliki pengetahuan asuransi dan dana pension sehingga dapat memperhatikan kehidupan peristiwa dan kondisi ekonomi yang berubah.Menurut Oliveira et al. (2019) financial literacy merupakan sebagai kemampuan untuk membuat penilaian berdasarkan pertimbangan dan untuk mengambil keputusan yang efektif tentang penggunaan dan manajemen uang. Dwiastanti (2015) mengemukakan bahwa financial literacy merupakan suatu alat yang dapat membantu para pemilik bisnis untuk dapat menjalankan bisnisnya serta memberikan pengetahuanpengetahuan keuangan untuk membuat keputusan mengenai konsekuensi keuangan dari keputusan tersebut. Jadi disini dapat kita simpulkan bahwa, financial literacy tidak hanya memberikan suatu pengetahuan-pengetahuan dasar saja melainkan juga memberikan pengetahuan mengenai sikap serta tingkah laku seseorang dalam membuat suatu tindakan sesuai dengan keputusan keuangan individu untuk merencakan keuangan masa depan.

Selain itu financial literacy memberi seorang individu atau pemilik bisnis kemampuan untuk membuat keputusan yang terinformasi dan efektif mengenai pengelolaan uang dalam pemahaman dan penerapan konsepkonsep keuangan. Maka dari itu, konsep financial literacy akan menjelaskan pengetahuan mengenai keuangan, kemampuan dalam memahami komunikasi mengenai konsep keuangan, kecakapan dalam mengelola suatu keuangan pribadi/perusahaan dan kemampuan melakukan keputusan keuangan dalam situasi tertentu.

Tabel 1

Indikator dan Item Financial Literacy

\begin{tabular}{|c|c|}
\hline Indikator & Item \\
\hline \multirow{3}{*}{$\begin{array}{l}\text { Basic Personal } \\
\text { Finance } \\
\text { (OECD, 2016) }\end{array}$} & $\begin{array}{l}\text { Saya mengetahui manfaat } \\
\text { pengetahuan keuangan. }\end{array}$ \\
\hline & $\begin{array}{l}\text { Saya mengetahui macam- } \\
\text { macam sumber } \\
\text { pendapatan dan } \\
\text { pengeluaran. }\end{array}$ \\
\hline & $\begin{array}{l}\text { Saya mengetahui cara } \\
\text { menyusun tujuan } \\
\text { keuangan jangka pendek, } \\
\text { menengah, dan panjang. }\end{array}$ \\
\hline \multirow[t]{6}{*}{$\begin{array}{l}\text { Manajemen Uang } \\
(\text { OECD, 2016) }\end{array}$} & $\begin{array}{l}\text { Saya mengetahui } \\
\text { pengelolaan keuangan. }\end{array}$ \\
\hline & $\begin{array}{l}\text { Saya mengetahui cara } \\
\text { mengelola keuangan yang } \\
\text { baik dan bijak. }\end{array}$ \\
\hline & $\begin{array}{l}\text { Saya mengetahui faktor- } \\
\text { faktor yang } \\
\text { mempengaruhi } \\
\text { pendapatan. }\end{array}$ \\
\hline & $\begin{array}{l}\text { Saya mengetahui } \\
\text { pengeluaran tidak terduga }\end{array}$ \\
\hline & $\begin{array}{l}\text { Saya mengetahui manfaat } \\
\text { penganggaran. }\end{array}$ \\
\hline & $\begin{array}{l}\text { Saya mengetahui manfaat } \\
\text { menabung di Bank. }\end{array}$ \\
\hline
\end{tabular}




\begin{tabular}{|c|c|}
\hline \multirow{6}{*}{$\begin{array}{l}\text { Tabungan dan } \\
\text { Investasi } \\
(\text { OECD, 2016) }\end{array}$} & $\begin{array}{l}\text { Saya mengetahui } \\
\text { karakteristik deposito. }\end{array}$ \\
\hline & $\begin{array}{l}\text { Saya mengetahui strategi } \\
\text { investasi pada deposito. }\end{array}$ \\
\hline & $\begin{array}{l}\text { Saya mengetahui strategi } \\
\text { investasi pada saham. }\end{array}$ \\
\hline & $\begin{array}{l}\text { Saya mengetahui } \\
\text { pengaruh suku bunga } \\
\text { terhadap harga obligasi. }\end{array}$ \\
\hline & $\begin{array}{l}\text { Saya mengetahui tentang } \\
\text { investasi jangka pendek. }\end{array}$ \\
\hline & $\begin{array}{l}\text { Saya mengetahui tentang } \\
\text { investasi jangka panjang. }\end{array}$ \\
\hline \multirow[t]{4}{*}{$\begin{array}{l}\text { Manajemen Resiko } \\
\text { (OECD, 2016) }\end{array}$} & $\begin{array}{l}\text { Saya mengetahui tujuan } \\
\text { utama memiliki asuransi. }\end{array}$ \\
\hline & $\begin{array}{l}\text { Saya mengetahui cara } \\
\text { membuka polis asuransi. }\end{array}$ \\
\hline & $\begin{array}{l}\text { Saya mengetahui faktor- } \\
\text { faktor yang } \\
\text { dipertimbangkan dalam } \\
\text { memilih jenis asuransi. }\end{array}$ \\
\hline & $\begin{array}{l}\text { Saya mengetahui } \\
\text { pengetahuan tentang } \\
\text { premi asuransi. }\end{array}$ \\
\hline \multirow[t]{3}{*}{$\begin{array}{l}\text { Kognitif } \\
\text { (OECD, 2016) }\end{array}$} & $\begin{array}{l}\text { Saya mempunyai } \\
\text { perencanaan keuangan } \\
\text { pribadi. }\end{array}$ \\
\hline & $\begin{array}{l}\text { Saya perlu untuk } \\
\text { memikirkan atau } \\
\text { merencanakan tentang } \\
\text { keuangan. }\end{array}$ \\
\hline & $\begin{array}{l}\text { Saya mencatat seluruh } \\
\text { transaksi keuangan saya }\end{array}$ \\
\hline \multirow[t]{4}{*}{$\begin{array}{l}\text { Afektif } \\
\text { (OECD, 2016) }\end{array}$} & $\begin{array}{l}\text { Saya lebih memilih } \\
\text { menggadaikan barang } \\
\text { untuk kebutuhan yang } \\
\text { tidak terduga. }\end{array}$ \\
\hline & $\begin{array}{l}\text { Saya menganggap } \\
\text { berhutang kepada orang } \\
\text { lain merupakan hal yang } \\
\text { wajar. }\end{array}$ \\
\hline & $\begin{array}{l}\text { Saya menggunakan } \\
\text { tabungan pribadi sebagai } \\
\text { pendanaan darurat. }\end{array}$ \\
\hline & $\begin{array}{l}\text { Saya menggunakan kredit } \\
\text { bank untuk mengatasi } \\
\text { kekurangan dana. }\end{array}$ \\
\hline $\begin{array}{l}\text { Perilaku atau } \\
\text { Tindakan } \\
(\text { OECD, 2016) }\end{array}$ & $\begin{array}{l}\text { Uang yang saya miliki } \\
\text { seluruhnya untuk } \\
\text { dibelanjakan. }\end{array}$ \\
\hline
\end{tabular}

\begin{tabular}{|l|l|}
\hline & $\begin{array}{l}\text { Kondisi keuangan saya } \\
\text { tidak menggangu } \\
\text { hubungan saya dengan } \\
\text { orang lain. }\end{array}$ \\
\cline { 2 - 2 } & $\begin{array}{l}\text { Belajar tentang keuangan } \\
\text { menjadi prioritas saya. }\end{array}$ \\
\hline
\end{tabular}

\section{Financial Behaviour}

Financial behaviour dianggap salah satu konsep yang terpenting didalam bidang keuangan. Menurut Dai (2016) mengatakan bahwa financial behavior sebagai faktor kognitif dari seseorang yang dapat mempengaruhi keputusan. Sedangkan secara keseluruhan dijelaskan oleh Yohana (2018) financial behavior merupakan suatu tindakan dalam pengambilan keputusan keuangan ataupun tanggung jawab dalam bidang keuangan. Sedangkan menurut Peter Kristofik (2018), ia mengatakan bahwa financial behavior tersebut merupakan suatu hal yang berkaitan dengan efektivitas manajemen dana. Financial behavior adalah suatu kemampuan seseorang yang dimilikinya dalam mengatur perencanaan keuangan, pengelolaan keuangan, pengendalian keuangan, pemeriksaan keuangan, pengendalian keuangan, dan bagaimana penyimpanan keuangan dalam dana sehari-hari (Herdjiono \& Damanik, 2016).

Sehingga dengan banyaknya pendapat dari para peneliti terdahulu yang menjelaskan tentang financial behavior maka kita akan tertarik untuk membahas mengenai financial behavior. Jadi financial behavior ini merupakan suatu tindakan yang dilakukan oleh seseorang secara sadar ataupun tidak sadar ketika melakukan tindakan keuangan tersebut. Banyak penelitian yang mengatakan bahwa financial behavior ini harus digabungkan dengan financial literacy dikarenakan dengan ilmu financial behavior ini merupakan gabungan dari teori behavioral dengan cognitive sehingga terjadi mengapa seseorang membuat tindakan keuangan secara irasional. Sehingga dengan adanya arahan dari financial literacy akan membuat seseorang tersebut lebih terarah sehingga akan memberikan dampak yang baik terhadap perusahaan.

Tabel 2

Indikator dan Item Financial Behaviour

\begin{tabular}{|l|l|}
\hline Indikator & \multicolumn{1}{c|}{ Item } \\
\hline & $\begin{array}{l}\text { Saya merasa perlu mengatahui } \\
\text { tentang penganggaran. }\end{array}$ \\
\hline
\end{tabular}




\begin{tabular}{|l|l|}
\hline \multirow{2}{*}{$\begin{array}{l}\text { Manajemen Arus } \\
\text { Kas }\end{array}$} & $\begin{array}{l}\text { Saya merasa perlu mengatahui } \\
\text { faktor-faktor yang } \\
\text { mempengaruhi penurunan } \\
\text { pengeluaran. }\end{array}$ \\
\cline { 2 - 2 } & $\begin{array}{l}\text { Saya merasa perlu } \\
\text { mengendalikan pengeluaran. }\end{array}$ \\
\hline $\begin{array}{l}\text { Manajemen } \\
\text { Kredit }\end{array}$ & $\begin{array}{l}\text { Saya membutuhkan investasi } \\
\text { untuk keperluan usaha saya. }\end{array}$ \\
\cline { 2 - 2 } OEC) & $\begin{array}{l}\text { Saya membayar kewajiban tepat } \\
\text { waktu. }\end{array}$ \\
\hline $\begin{array}{l}\text { Manajemen } \\
\text { Tabungan } \\
\text { (OECD, 2016) }\end{array}$ & $\begin{array}{l}\text { Saya memiliki manajemen } \\
\text { hutang dan tabungan dalam } \\
\text { mengelola usaha. }\end{array}$ \\
\hline
\end{tabular}

\section{Firm Performance}

Perusahaan pada umumnya akan memiliki tujuan tertentu yang ingin dicapai dalam usaha untuk memenuhi kepentingan para anggotannya. Keberhasilan atas yang dilakukan terhadap perusahaan merupakan suatu prestasi manajemen. Penilaian prestasi atau kinerja tersebut pada suatu perusahaan akan diukur karena akan dapat dipakai sebagai dasar pengambilan keputusan baik untuk pihak internal maupun eksternal (Hidayati, 2019). Firm performance dapat dikatakan sebagai suatu usaha formal yang dilakukan perusahaan untuk mengevaluasi efisiensi dan efektivitas dari aktivitas perusahaan yang telah dilaksanakan pada suatu periode tertentu. Sehubungan dengan itu, Sanistasya et al. (2019) mendefinisikan firm performance sebagai suatu analisis yang dilakukan untuk melihat sejauh mana telah melakukan dengan menggunakan aturan-aturan pelaksanaan yang baik dan benar secara financial dan non-financial.

Pengukuran kinerja dapat memainkan peran penting dalam mengevaluasi kinerja keseluruhan perusahaan. Sebagai indikator penting dari seberapa baik perusahaan menggunakan asetnya untuk meningkatkan keuntungan perusahaan (Herdjiono \& Damanik, 2016). Semua perusahaan harus menyiapkan keuangan mereka, seperti data akuntansi seperti total penjualan, total pendapatan, total pengeluaran, gaji dan upah, laba, laba atas ekuitas, omset dan bersih pendapatan.

Kombinasi informasi keuangan dan nonkeuangan sangat penting untuk memberi lebih banyak kesan seimbang dari keseluruhan firm performance (Sanistasya et al., 2019). Pentingnya mengintegrasikan kinerja nonkeuangan ke dalam tindakan yang didokumentasikan dengan baik. Ukuran kinerja non-financial dapat didefinisikan sebagai ukuran yang menyediakan informasi kinerja. Ini termasuk kualitas desain, peningkatan produk, tindakan pelanggan atau pasar, tindakan operasi, pengembangan pemangku kepentingan dan persiapan untuk langkah-langkah masa depan sehingga dengan mempertahankan indikator keuangan tetapi juga memperhatikan indikator non-keuangan akan memungkinkan perusahaan untuk melacak hasil keuangan sambil secara bersamaan memantau kemajuan dalam membangun kemampuan dan memperoleh keuntungan yang mereka butuhkan untuk pertumbuhan di masa depan. Sanistasya et al. (2019) berpendapat bahwa keberhasilan tidak hanya bergantung pada pencapaian ukuran finansial, tetapi juga pada seberapa baik suatu perusahaan beradaptasi dengan lingkungan di mana ia ada.

Tabel 3

Indikator dan Item Firm Performance

\begin{tabular}{|l|l|}
\hline \multicolumn{1}{|c|}{ Indikator } & \multicolumn{1}{|c|}{ Item } \\
\hline $\begin{array}{l}\text { Kinerja } \\
\text { Keuangan } \\
\text { (Grohmann, } \\
2018)\end{array}$ & $\begin{array}{l}\text { Saya merasa bisnis saya } \\
\text { menguntungkan. }\end{array}$ \\
\cline { 2 - 2 } & $\begin{array}{l}\text { Saya merasa bisnis saya terus } \\
\text { berkembang. }\end{array}$ \\
\cline { 2 - 2 } Non- & $\begin{array}{l}\text { Saya memiliki karyawan tetap } \\
\text { yang sesuai dengan kebutuhan } \\
\text { bisnis saya. }\end{array}$ \\
\hline $\begin{array}{l}\text { Keuangan } \\
\text { (Grohmann, } \\
2018)\end{array}$ & $\begin{array}{l}\text { Saya merasa kualitas } \\
\text { manajemen bisnis saya baik. }\end{array}$ \\
\cline { 2 - 2 } & $\begin{array}{l}\text { Saya merasa kualitas produk } \\
\text { saya membaik. }\end{array}$ \\
\cline { 2 - 2 } & $\begin{array}{l}\text { Saya yakin inovasi bisnis saya } \\
\text { terus berkembang. }\end{array}$ \\
\cline { 2 - 2 } & $\begin{array}{l}\text { Saya yakin bahwa saya } \\
\text { mampu mempertahankan } \\
\text { orang - orang berbakat yang } \\
\text { ada dalam bisnis saya. }\end{array}$ \\
\hline
\end{tabular}

Penelitian Oliveira et al. (2019) penelitian ini menjelaskan mengenai meta analitik pada financial literacy terhadap financial behavior yang mendukung pengambilan keputusan jangka pendek dan perencanaan keuangan jangka panjang yang baik. Variabel yang digunakan yaitu financial literacy dan financial behaviour. Jumlah sampel yang digunakan 44 studi yang valid, yang menghasilkan total 690 pengamatan. Penelitian ini dilakukan dengan menggunakan panel regresi pada studi kasus. Dalam penelitian ini, financial literacy memiliki indikator financial attitude, financial behaviour, dan financial knowledge. Serta pada financial 
behaviour yang diteliti yaitu Behaviour of avoidable credit and checking fees, dan Credit card behaviours. Dalam penelitian ini, hasilnya menunjukkan bahwa financial literacy memiliki pengaruh yang signifikan terhadap financial behaviour. Dengan terus memperhatikan financial literacy maka akan dapat membuat financial behavior lebih terarah dalam jangka panjang.

Penelitian Assaf (2019), pada penelitian ini menggunakan pendekatan kuantitatif. Data yang ada dalam penelitian ini, diambil dari wawancara dan kuesioner dengan 215 responden. Penelitian ini terdapat teknik pengumpulan data yang digunakan yakni menggunakan angket atau kuesioner dan wawancara. Kuesioner yang didalamnya berisi profil responden serta pernyataan tertutup yang terdiri atas beberapa pilihan jawaban. Sedangkan skala pernyataan yang digunakan peneliti adalah skala likert dengan menggunakan berbagai item pertanyaan penelitian. Dalam penelitian ini menggunakan metode analisis regresi linear berganda. Analisis regresi linear berganda ini dipilih dan dilakukan pada penelitian karena jumlah variabel independen lebih dari satu. Sedangkan alat analisis yang dipakai dalam penelitian ini menggunakan software SPSS Versi 24.

Dalam penelitian ini hanya locus of control dan financial self-efficacy yang memiliki pengaruh signifikan terhadap financial management behavior. Selain itu demografi, financial knowledge dan financial attitude tidak memiliki pengaruh terhadap financial behavior. Oleh karena itu, hasil ini bertentangan dengan teori yang sudah dijelaskan sebelumnya. Maka dari itu, semakin masyarakat tersebut dapat mengontrol dirinya dari pengaruh pribadi maupun lingkungan akan memiliki tingkat yang baik terhadap financial management behavior.

Penelitian Grohmann (2018) Pada penelitian ini menguji variabel financial literacy terhadap financial behavior. Sampel dalam penelitian ini terjadi di sektor kalangan menengah di daerah Bangkok. Dengan menggunakan teknik pengumpulan wawacara di berbagai 28 lokasi perumahan di daerah Bangkok. Pada sampel tersebut menghasilkan data yang signifikan antara variabel financial literacy terhadap financial behavior dengan menggunakan analisis data SEM. Maka dari itu, semakin tinggi tingkat financial literacy pada suatu masyarakat di suatu daerah maka akan meningkatkan juga financial behavior masyarakat tersebut.

Penelitian Esiebugie (2018), pada penelitian ini menggunakan sumber primer dan sekunder dari sampel 154 responden yang diperoleh dengan menggunakan kuesioner yang terstruktur dan Peneliti mengadopsi teknik pengambilan sampel proporsional berstrata. Data yang dikumpulkan dianalisis menggunakan statistik deskriptif seperti frekuensi, persentase sederhana dan hubungan antara variabel model diuji menggunakan analisis regresi linier berganda. Populasi target terdiri dari 250 UKM terdaftar di empat subsektor di kota metropolitan menurut Benue Kamar Dagang, Industri, Tambang dan Pertanian. Pada penelitian ini menggunakan alat analisis SEM yang memberikan hasil bahwa financial literacy yang terdiri dari financial knowledge, financial attitude serta financial behavior hanya financial knowledge dan financial attitude yang memiliki pengaruh terhadap performance, sedangkan financial behavior tidak memiliki pengaruh yang signifikan terhadap performance.

Penelitian Uc. ediringhe et al. (2019), pada penelitian ini menjelaskan financial literacy terhadap financial behavior pada universitas-universitas pemerintahan pada Sri Lanka. Sampel yang digunakan dalam penelitian ini dengan memilih 223 responden menggunakan kuesioner secara kuantitatif yang dibagikan kepada ketiga universitas-universitas pemerintahan tersebut. Pada penelitian ini financial literacy menjelaskan bagaimana seseorang tersebut bisa mengerti mengenai financial literacy terkait, manajemen uang, tabungan, investasi, kredit dan asuransi. Secara keseluruhan financial literacy ini akan mempengaruhi financial behavior seseorang. Sehingga dalam penelitian ini financial literacy memiliki dampak yang signifikan terhadap financial behavior dengan menggunakan analisis regresi berganda secara keseluruhan.

Penelitian Aribawa (2014), pada penelitian ini menggunakan pengambilan sampel yang digunakan adalah purposive sampling, dengan kriteria sebagai berikut: 1) Memiliki keunikan (menawarkan produk atau jasa lebih dari satu macam) 2) Beroperasi atau memiliki kantor pusat di cakupan wilayah penelitian. Pada penelitian ini Data terkumpul dianalisis menggunakan model persamaan struktural berbasis partial least square. Software Smart PLS 3.0 ini digunakan untuk 
membantu menganalisis hubungan antar variabel. Hasil dari penelitian ini adalah financial literacy memiliki pengaruh yang signifikan terhadap performance dan sustainability. Oleh karena itu, semakin tinggi tingkat financial literacy maka akan membawa dampak yang baik terhadap performance dan sustainability.

Penelitian Eniola \& Entebang (2015), pada penelitian ini menguji variabel financial literacy terhadap firm performance pada UMKM di negara Nigeria. Penelitian ini menggunakan pendekatan kuantitatif. Dengan sampel penelitian yang memiliki pendapatan diatas 50 juta. Data dianalisis dengan SEM dan menghasilkan bahwa financial literacy tidak memiliki pengaruh yang signifikan terhadap firm performance pada negara Nigeria. Hasil ini didapatkan karena keterbatasan dari penelitian yang kurang kompleks di berbagai daerah. Sehingga menjadikan hasil yang bertolak belakang dengan teori yang ada sebelumnya. Model yang digunakan dalam penelitian ini dengan membagi financial literacy menjadi financial knowledge, financial attitude serta awareness terhadap firm performance.

Penelitian Dwiastanti (2015),pada penelitian ini menggunakan pendekatan kuantitatif. Dengan menguji adanya hubungan yang signifikan antara variabel financial literacy terhadap financial behavior. Teknik pengambilan sampel yang dilakukan dengan menggunakan purposive sampling. Dengan menggunakan teknik pengujian ANOVA penelitian ini menjadi valid terkait hasil penelitian. Maka dari itu, semakin tinggi tingkat financial literacy maka akan mempengaruhi tingkat financial behavior.

Penelitian Hidayati (2019), pada penelitian ini financial behaviour terbagi menjadi mental accounting, overconvidence serta risk sttitude. Penelitian ini dilakukan pada UKM di daerah Lombok. Penelitian ini menggunakan teknik pengambilan sampel dilakukan dengan non probability sampling, yaitu menggunakan judgment sampling. Sampel yang diambil pada penelitian ini yaitu UKM yang bergerak pada industri gerabah dan sudah melakukan ekspor. Responden penelitian ini pada manajer sekaligus pemilik UKM. Metode analisis data yang digunakan Generalized Structured Component Analysis. Hasil penelitian menunjukkan risk attitudes, mental accounting dan overconfidence bersifat rasional dan berpengaruh signifikan terhadap kinerja perusahaan melalui variabel mediasi keputusan penempatan dana untuk modal kerja. Hal ini yang dilatarbelakangi oleh sebagian besar manajer sekaligus pemilik UKM yaitu laki-laki, usia masih produktif dan pengalaman dalam bidangnya lebih dari 10 tahun. Risk attitudes memiliki pengaruh tidak signifikan terhadap kinerja UKM karena penempatan dana untuk modal kerja merupakan variabel mediasi sempurna, selain itu juga disebabkan oleh latar belakang pendidikan yang tingkat menengah dan kepemilikan UKM yang bersifat perorangan pada masing-masing manajer UKM. Keputusan penempatan dana untuk modal kerja memiliki pengaruh signifikan terhadap kinerja UKM. Keputusan penempatan dana untuk modal kerja ditunjukkan dengan terjadinya efisiensi pada manajemen kas, piutang dan persediaan sehingga hal ini dapat meningkatkan kinerja perusahaan.

Penelitian Adomako \& Danso (2014), Pada penelitian ini mencari hubungan keterkaitan secara langsung maupun tidak langsung antara variabel financial literacy terhadap firm performance, serta variabel financial literacy yang dimediasi oleh variabel financial capital availaibility dan resource flexibility. Pemilihan sampel yang dilakukan terletak pada kota Graha yang merupakan negara berkembang dengan mengambil sampel sebanyak 969 perusahaan. Maupun kriterianya antara lain adalah memiliki perusahaan entitas yang independen tanpa afiliasi dengan grup atau rantai perusahaan manapun. Lalu perusahaan yang dimiliki harus dikendalikan oleh perorangan atau kelompok yang setidaknya memiliki kepemilikan sebesar 50\% pada perusahaan tersebut, perusahaan harus menjadi produsen produk fisik atau penyedia layanan yang terlibat dalam kegiatan bisnis yang produktif. perusahaan dengan pengalaman operasi bisnis minimal lima tahun. Pada penelitian ini juga menggunakan skala likert dengan menyertakan berbagai pernyataanpernyataan yang dilakukan untuk data kedepannya. Pada penelitian ini menggunakan variabel kontrol yang diadopsi dalam penelitian ini termasuk ukuran perusahaan, industri perusahaan, usia perusahaan dan usia pengusaha.

Hasil penelitian ini menunjukkan (1) financial literacy secara positif terkait dengan firm performance, (2) financial capital availibility secara positif memoderasi hubungan antara financial literacy dan firm performance, 
(3) resources fleksibility secara positif memoderasi hubungan antara financial literacy dan firm performance. Dengan demikian, kami menemukan bahwa financial literacy meningkatkan firm performance dan khususnya ketika resouces flexibility dan ketika pengusaha dapat mengakses keuangan dengan mudah. Sehingga hasil menyiratkan bahwa sumber daya yang fleksibel dan akses ke modal keuangan adalah sumber daya yang berharga untuk meningkatkan hubungan financial literacy terhadap firm performance.

Penelitian Kumar et al. (2017), Pada penelitian ini mengunakan pendekatan kuantitatif. Penelitian ini memiliki sampel 79 siswa pada suatu daerah. Penelitian ini menyelidiki pengaruh serta dampak dari financial literacy dan financial education terhadap financial behavior. Sebanyak 400 kuesioner yang dibagikan dan yang kembali sebanyak 79 kuesioner serta analisis lebih lanjut. Data dianalisis dengan SEM dan menghasilkan bahwa financial literacy dan financial education memiliki pengaruh yang signifikan terhadap financial behavior.

\section{METODE PENELITIAN}

Pada paper ini merupakan conceptual paper menggunakan literature review, dimana literature review ini digunakan untuk merekap penelitian-penelitain terdahulu. Penelitian penelitian terdahulu ini akan dijabarkan dan ditelaah satu per satu sehingga akan menemukan research gap penelitian.

Dalam penelitian ini penulis memberikan kata kunci untuk mempermudah langkah menemukan berbagai jurnal-jurnal yang dibutuhkan dalam paper ini. Jurnal - jurnal tersebut berkaitan dengan tema paper ini seperti, financial literacy, financial behaviour dan firm performance. Kata kunci selanjutnya penulis masukan kedalam emerald insight, science direct dan google schooler.

Penemuan jurnal-jurnal tersebut akan dilakukan secara cermat dan teliti dengan memasukkan kata kunci "Financial Literacy" kedalam emerald insight journal maka kemudian ditemukan sebanyak 47.554 artikel yang meneliti financial literacy dalam kurun waktu 7 tahun terakhir yang dimulai dari tahun 2014 sampai dengan 2019. Kemudian ketika dimasukan "financial literacy" kedalam science direct ditemukan sebanyak 15.886 artikel yang meneliti tentang financial literacy yang dimulai dari tahun 2014 sampai dengan 2019. Serta ketika dimasukan kata "financial literacy" kedalam google schooler ditemukan sebanyak 17.900 artikel yang meneliti tentang financial literacy.

Penulis juga menjadikan financial behaviour sebagai kata kunci untuk mendapatkan jurnal-jurnal yang terkait dengan penelitian. Ketika dimasukkan kedalam emarald insight journal ditemukan sebanyak 16.887 artikel yang meneliti mengenai financial behaviour. Kemudian dimasukkan kata kunci financial behaviour kedalam science direct ditemukan sebanyak 14.554 artikel yang meneliti tentang financial behaviour. Kemudian ketika dimasukan kedalam google schooler ditemukan sebanyak 11.224 artikel yang meneliti tentang financial behaviour.

Firm performance juga dijadikan kata kunci untuk menemukan jurnal-jurnal yang dibutuhkan didalam paper ini. Ketika penulis memasukan kata kunci firm performance kedalam emarld insight ditemukan sebanyak 14.834 artikel yang mengatakan bahwa banyak peneliti yang meneliti firm performance. Ketika kata kunci firm performance tersebut dimasukkan kedalam science direct maka ditemukan sebanyak 11.673 artikel yang mengatakan bahwa banyaknya peneliti yang meneliti mengenai firm performance. Ketika kata kunci tersebut juga dimasukkan kedalam google schooler, maka ditemukan sebanyak 12.653 artikel yang mengatakan bahwa banyaknya peneliti yang meneliti terkait firm performance.

Hal ini tidak sampai disana, penulis mengecilkan kemungkinan kemunculan jurnal dengan memberikan kata kunci financial literacy, financial behaviour dan firm performance secara bersamaan kedalam ketiga portal jurnal tersebut yaitu emarld insght, science direct dan google schooler. Ditemukan 52 pada portal emarld insght, 72 pada portal science direct dan 43 pada portal google schooler. Namun, hanya sebanyak 11 jurnal yang digunakan sebagai pendukung dalam hipotesis paper ini. Dalam 11 jurnal tersebut dipilih dikarenakan dalam jurnal tersebut terdapat item-item dan indikator yang jelas, lengkap serta terukur. Di dalam jurnal tersebut dijelaskan juga bagaimana pengukuran financial literacy, financial behaviour, dan firm performance menggunakan skala likert. Serta dalam jurnal tersebut juga menggunakan pendekatan kuantitatif yang juga mendukung referensi yang dibutuhkan pada paper ini. 


\section{KESIMPULAN DAN SARAN Kesimpulan}

Dalam tulisan ini menggunakan penelitian - penelitian terdahulu. Penelitian penelitian terdahulu tersebut digunakan untuk mendapatkan research gap. penelitian terdahulu tersebut digunakan untuk mencari bagaimana pentingnya financial literacy. Financial literacy sudah sangat semakin melemah dikalangan para pebisnis yang memiliki usaha bisnis ataupun yang memiliki perusahaan.

Kebanyakan dari para pebisnis yang memiliki perusahaan didominasi oleh generasi muda atau kalangan millenial. Sehingga ketika membuat suatu keputusan juga ditentukan dari pada pemilik bisnis tersebut. Akan tetapi, menurut data dari Otoritas Jasa Keuangan 2019 menganai tingkatan literasi nasional mengatakan bahwa sangat rendahnya tingkat melek baca yang dimilki oleh para masyarakat indonesia.

Pada tahun 2019 tersebut mengatakan bahwa literacy ini lemah kebanyakan didominasi oleh kalangan muda sebagai youth entrepreneur. Mereka masih lemah dalam membaca, memahami, serta menelaah kemampuan mereka dalam bidang pengetahuan. Padahal, semakin rendahnya literacy seseorang yang memiliki bisnis akan berpengaruh terhadap bagaimana mereka menjalankan sebuah bisnis yang akan berpengaruh terhadap kinerja perusahaan.

Financial literacy yang semakin lemah dipicu dengan berbagai faktor, antara lain adalah faktor pemeritah. Pemerintah masih kurang tanggap dalam mengatasi literacy pada masyarakat sehingga terjadi penurunan yang sangat tajam pada tahun 2019. Kurangnya pelatihan yang diberikan oleh pemerintah dan kebijakan pemerintah terhadap para pemangku bisnis yang masih dalam kalangan anak muda tersebut.

Financial literacy lemah juga dikarenakan kurangnya pelatihan yang diberikan perusahaan dalam waktu tertentu. Sehingga akan berlama-lama yang akan menimbulkan kelemahan dalam bidang pengetahuan. Kelemahan tersebut akan membuat seorang pebisnis sulit melihat peluang-peluang bisnis yang seharusnya dapat menjadi bahan untuk meningkatkan kemajuan bisnisnya.
Selain itu, dengan adanya financial behaviour yang baik dalam diri seseorang akan berdampak secara baik pula terhadap firm performance. Ketika seseorang memiliki perilaku yang baik maka mereka akan terarah dalam menjalankan bisnis. Behaviour disini tidak hanya faktor afektif saja akan tetapi juga dipengaruhi secara cognitive, dimana mereka ketika menjalankan suatu bisnis akan dipengaruhi adanya tindakan secara tidak sadar dalam membuat suatu keputusan yang secara tidak langsung juga akan berpengaruh kepada firm performance.

Secara keseluruhan dijelaskan bahwa memang sangat penting untuk mempelajari serta mendalami financial literacy, dengan adanya pemahaman financial literacy yang baik maka akan mengerti bagaimana mengelola keuangan, mengelola uang masuk dan uang keluar serta juga memiliki pengetahuan mengenai investasi pada saham ataupun mengelola uang dalam jangka panjang. Financial literacy yang baik juga akan dapat memprediksi yang akan terjadi dalam waktu dekat ataupun dalam waktu yang lama yang secara langsung akan menggambarkan firm performance.

\section{Saran}

Penelitian mengenai financial literacy dari penelitian terdahulu sampai sekarang menjadi suatu hal yang sangat penting untuk dibahas dikarenakan akan menggambarkan bagaimana seseorang dalam mengambil keputusan berdasarkan pengetahuan yang ia miliki yang akan meningkatkan keuntungan bisnis atau menurukan keuntungan bisnis baik dalam jangka pendek maupun dalam jangka panjang.

Kebijakan pemerintah dalam mengatasi kelemahan financial literacy ini sangat didukung agar para pebisnis tidak mengalami tingkat melek baca yang sangat rendah dari tahun ke tahun. Selain itu, alangkah baiknya kebijakan pemerintah ini dilakukan dengan secara rutin dan bertahap sehingga lebih terarah dalam menentukan sebuah kebijakan.

Bagi pemilik bisnis, alangkah baiknya terus melakukan pelatihan dan penanganan lebih lanjut terkait pengetahuan yang dimiliki ketika menjalankan sebuah bisnis. Bisnis yang masih kurang pengetahuan maka akan bangkrut. Oleh karena itu, literacy dalam perusahaan harus sangatlah diperhatikan terkait bagaimana meraka mengatasi, mengontrol serta 
memahami pentingnya literacy untuk mendapatkan keuntungan yang besar pada periode tertentu.

Selain itu, penelitian kedepannya dapat memeriksa dan memperhatikan apa-apa saja yang menjadi faktor-faktor pendorong dalam firm performance dan juga memperhatikan faktor cognitive seseorang dalam membuat suatu keputusan secara tidak langsung yang juga akan berdampak secara tidak langsung ke firm performance.

\section{DAFTAR PUSTAKA}

Adomako, S., \& Danso, A. (2014). Financial Literacy and Firm performance The moderating role of financial capital availability and resource flexibility.

Amanah, E., Iradianty, A., \& Rahardian, D. (2016). Pengaruh Financial Knowledge , Financial Attitude Dan External Locus of Control Terhadap Personal Financial Management Behavior Pada Mahasiswa S1 Universitas Telkom the Influence of Financial Knowledge, Financial Attitude and External Locus of Control on. EProceeding of Management, 3(2), 12281235.

Dai, R. M. (2016). The effect of behavioral finance on financial performance leading medium entreprises. 4(1), 57-62.

Dessyana, A., \& Dwi Riyanti, B. P. (2017). The Influence of Innovation and Entrepreneurial Self-Efficacy to Digital Startup Success. International Research Journal of Business Studies, 10(1), 57-68. https://doi.org/10.21632/irjbs.10.1.57-68

Dwiastanti, A. (2015). Financial Literacy as the Foundation for Individual Financial Behavior. Journal of Education and Practice, 6(33), 99-105. Retrieved from http://www.eric.ed.gov/contentdelivery/s ervlet/ERICServlet?accno=EJ1083664

Dwitya Aribawa. (2014). Pengaruh literasi keuangan terhadap kinerja dan keberlangsungan UMKM. Oral and Maxillofacial Surgery, 18(4), 425-430. https://doi.org/10.1007/s10006-0130431-4

Eniola, A. A., \& Entebang, H. (2015). Financial literacy and SME firm performance. International Journal of Research Studies in

Management,

$5(1)$.

\section{https://doi.org/10.5861/ijrsm.2015.1304}

Esiebugie, U. (2018). Financial literacy and performance of small and medium scale enterprises in Benue State, Nigeria. International Journal of Economics, Business and Management Research, 2(4), 65-79.

Grohmann, A. (2018). Financial literacy and financial behavior: Evidence from the emerging Asian middle class. Pacific Basin Finance Journal, 48(July 2017), 129-143.

https://doi.org/10.1016/j.pacfin.2018.01.0 07

Herdjiono, I., \& Damanik, L. A. (2016). Pengaruh Financial Attitude, Financial Knowledge, Parental Income Terhadap Financial Management. Jurnal Manajemen Teori Dan Terapan Universitas Musamus, 9(3), 226-241.

Hidayati dkk, S. A. (2019). Mental Accounting Dan Dampaknya Terhadap Kinerja Perusahaan Melalui Penempatan Modal Kerja Pada Usaha Kecil Dan Menengah Di Pulau Lombok. Journal of Chemical Information and Modeling, 53(9), 16891699.

https://doi.org/10.1017/CBO9781107415 324.004

Humaira, I., \& Sagoro, E. M. (2018). Pengaruh Pengetahuan Keuangan, Sikap Keuangan, Dan Kepribadian Terhadap Perilaku Manajemen Keuangan 7(1). https://doi.org/10.21831/nominal.v7i1.19 363

Kalaipriya, K. (2018). The Relationship between Access to Finance and Growth of SMEs in the Northern Province of Sri Lanka : Financial Literacy as a Moderator. 15th International Conference on Business Management, (Icbm), 567-589.

Kojo Oseifuah, E. (2010). Financial literacy and youth entrepreneurship in South Africa. African Journal of Economic and Management Studies, 1(2), 164-182. https://doi.org/10.1108/20400701011073 473

Krištofík, P. (2018). The Impact of behavioral finance on the Financial Performance of an Organization. Asia Proceedings of Social Sciences, 2(2), 123-127. 
https://doi.org/10.31580/apss.v2i2.391

Kumar, S., Watung, C., N. Eunike, J., \& Luinata, L. (2017). The Influence of Financial Literacy Towards Financial Behavior and Its Implication on Financial Decisions: A Survey of President University Students in Cikarang - Bekasi. Firm Journal of Management Studies, 2(1), 169-179. Retrieved from http://ejournal.president.ac.id/presunivojs/index. php/FIRM-

JOURNAL/article/view/158/87

Laili Riskiawati, Nur Asandimitra Haryono, N. (2018). Pengaruh Demografi, Financial Knowledge, Financial Attitude, Locus of Control Dan Financial Self-Efficacy Terhadap Financial Management Behavior Masyarakat Surabaya. Jurnal Ilmu Manajemen (JIM), 6(3).

Lianto, R., \& Elizabeth, S. M. (2017). Analisis pengaruh financial attitude, financial knowledge, income terhadap financial behavior. 1-12.

Listiani, K. (2017). Pengaruh Financial Knowledge, Locus of Control dan Financial Attitude Terhadap Financial Management Behavior Pada Mahasiswa. Artikel Stie Perbanas Surabaya.

OECD. (2016). OECD Multilingual Summaries Education at a glance $2016 \mathrm{http} / /$ doi.org/10.1787/eag-2016-en.

Oliveira, F. De, Ladeira, W. J., Mette, F. M. B., $\&$ Ponchio, M. C. (2019). The antecedents and consequences of financial literacy: a meta-analysis. International Journal of Bank Marketing. https://doi.org/10.1108/IJBM-10-20180281

Peter Kristofik, M. N. (2018). The impact of behavioral finance on the financial performance of an enterprise The impact of behavioral finance on the financial performance of an enterprise. (1). https://doi.org/10.13140/RG.2.2.32010.1 6328

Rafiqah Assaf, S. (2019). Pengaruh financial attitude, financial knowledge terhadap financial management behavior. Jurnal of Economic, szzzzzzzManagement and Accounting, 2(2), 68-74.

Ratnawati. (2016). Tingkat Pendididkan,
Pengetahuan Literasi Keuangan, Sustainability Usaha Sebagai Upaya Meningkatkan Kinerja Manajemen UKM. Ilmiah - Vidya, 24(2), 24-32.

Sanistasya, P. A., Raharjo, K., \& Iqbal, M. (2019). The Effect of Financial Literacy and Financial Inclusion on Small Enterprises Performance in East Kalimantan. Jurnal Economia, 15(1), 4859.https://doi.org/10.21831/economia.v1 5i1.23192

Uc. ediringhe, y.m.s. keertipala, a. r. amarashinge. (2019). Financial literacy and financial behavior of management Financial Literacy in Europe, (July), 85140.https://doi.org/10.4324/97804294319 68-3

Yohana, I. (2010). Pengaruh locus of focus, income, financial knowledge terhadap financial management behavior. Jurnal Bisnis Dan Akuntansi, 12(3), 131-144.

Yohana, I. dan. (2018). The impact of behavioral finance on the financial performance of an enterprise The impact of behavioral finance on the financial performance of an enterprise. (1). https://doi.org/10.13140/RG.2.2.32010.1 6328 